\title{
The Effect of Hydrology on Soil Erosion
}

\author{
Jesús Rodrigo-Comino ${ }^{1,2, * \mathbb{D}}$, José María Senciales-González ${ }^{3} \mathbb{D}$ and José Damián Ruiz-Sinoga ${ }^{3}$ \\ 1 Physical Geography, Trier University, 54286 Trier, Germany \\ 2 Soil Erosion and Degradation Research Group, Department of Geography, University of Valencia, \\ 46010 Valencia, Spain \\ 3 Department of Geography, Málaga University, Campus of Teatinos s/n, 29071 Málaga, Spain; \\ senciales@uma.es (J.M.S.-G.); sinoga@uma.es (J.D.R.-S.) \\ * Correspondence: rodrigo-comino@uma.es
}

Received: 11 March 2020; Accepted: 15 March 2020; Published: 16 March 2020

check for updates

\begin{abstract}
In this Special Issue, we have tried to include manuscripts about soil erosion and degradation processes and the accelerated rates due to hydrological processes and climate change. We considered that the main goal was successfully reached. The new research focused on measurements, modelling, and experiments under field or laboratory conditions developed at different scales (pedon, hillslope, and catchment) were submitted and published. This Special Issue received investigations from different parts of the world such as Ethiopia, Morocco, China, Iran, Italy, Portugal, Greece and Spain, among others. We are happy to see that all papers presented findings characterized as unconventional, provocative, innovative and methodologically new. We hope that the readers of the journal Water can enjoy and learn about hydrology and soil erosion using the published material, and share the results with the scientific community, policymakers and stakeholders new research to continue this amazing adventure, featuring plenty of issues and challenges.
\end{abstract}

Keywords: hydrological processes; soil erosion; different scales; models; experiments

\section{Introduction}

Soil erosion is one of the most important environmental issues in natural and anthropized territories [1,2]. Understanding the key parameters and factors of soil erosion will enable the conservation of soil system goods, services and resources, and will avoid the damage outside of fields caused by transported and accumulated sediments and water [3,4]. The dynamics of erosive processes are changing along with new trends of pluviometric patterns due to well-identified climate change, which is becoming an extra factor in soil degradation [5,6]. However, in several parts of the world, this problem is currently not well-understood because of the lack of information, or simply because it is ignored. This is the case in several parts of Africa or Asia or for land uses such as urban areas, vineyards or abandoned plots [7-9].

In this Special Issue, we attempted to discuss and address the state-of-the-art of soil erosion and degradation processes because of their accelerated rates due to hydrological processes and climate change but also due to non-controlled human impacts. To fill these gaps, studies focused on measurements, modelling, and experiments under field and laboratory conditions developed at different scales (pedon, hillslope, and catchment) were particularly welcome for submission. Understanding the effects of hydrology is complex, and a combination of several natural and anthropic mechanisms must be understood such as climate change, tillage effects, rill and interrill occurrence, gully formation, soil compaction and water losses, runoff generation thresholds, soil salinization, organic matter depletion, and so on. 


\section{Summary of This Special Issue}

Two papers were published related to laboratory research. To understand soil erosion processes, each pedological, climate, geomorphological and hydrological parameter must be assessed. In Fernández-Raga et al. [10], the authors highlighted the need to choose the most correct measurement device during the experimental design; for example, in the case of splash erosion. They evaluated the hydrological response under different intensities of simulated rainfall of different devices under the same conditions. On the other hand, Meshkat et al. [11] assessed the geometry of hillslopes (plan and profile), which can affect soil erosion under rainfall-runoff processes. They studied the impact of surface roughness coefficients and complex hillslopes on runoff variables viz. their time of generation, time of concentration, and peak discharge value, with a total of 81 experiments under laboratory conditions.

Soil erosion also affects anthropized areas. In this Special Issue, three interesting manuscripts were published providing new insights about peri-urban areas, agricultural fields and soil conservation measures in forestry areas. Ferreira et al. [12] confirmed that understanding sediment dynamics in peri-urban catchments constitutes a research challenge because of the spatiotemporal complexity and variability of the land-uses involved. This research group analyzed differences in the concentration of total sediments and suspended sediments in the small peri-urban Mediterranean Ribeira dos Covões catchment ( $40 \%$ urban area) in central Portugal. The results provided key data about sediment dynamics to help stakeholders to establish strategies to reduce risks and reduce the impacts on urban aquatic ecosystems.

Capello et al. [13] illustrated that soil erosion in vineyards continues to be affected by soil erosion. This study case evaluated the impacts of rainfall temporal patterns and intensity variability when machine traffic is implemented with particular intensity from late spring to harvest. The results showed that soil management generated soil compaction, which likely affects soil hydraulic properties, runoff, and soil erosion. The authors stated that there is a real need to limit tractor traffic and to reduce negative effects due to soil compaction, especially in tilled inter-rows.

Another clear example of human disturbance is the research published by Mhiret et al. [14] about land degradation and soil conservation measures carried out to reduce soil loss in the Ethiopian Highlands. This territory suffers from severe land degradation, including erosion, and in response, the Ethiopian government has implemented soil and water conservation practices considering the acreage of eucalyptus, which has been expanded. They examined the impacts of these land-use changes on stream discharge and sediment load in a sub-humid watershed, collecting a total of 867 storm events for nine years. The results indicated that the techniques are either inappropriate for this sub-humid watershed or require improved design and maintenance.

Kirchhoff et al. [15] presented exotic research carried out in a poorly-studied region of Northern Africa, where the endemic argan tree (Argania Spinosa) populations are highly degraded due to their use as a biomass resource in dry years and illegal firewood extraction. In total, 36 rainfall simulation experiments, as well as 60 infiltration measurements, were conducted to investigate the potential difference between tree-covered areas and bare inter-tree spaces. They concluded that argan trees have a great influence on the soil underneath; meanwhile, the soil in intertree areas is less protected and more degraded. They stated that it can be supposed that there will be further soil degradation when intertree areas extend further due to the lack of rejuvenation of argan trees.

Finally, the rest of the published papers were related to modelling techniques of Earth surface landforms (e.g., gullies) and processes (e.g., landslides) or the quantification of soil erosion rates. In particular, two papers published here showing different study cases from China are very interesting. Yan et al. [16] explained that since large-scale agricultural irrigation began in the 1980s on the South Jingyang Plateau, 92 landslides have occurred. As a result, numerous casualties and substantial property loss have been caused. In their manuscript, the authors evaluated the soil erosion and mechanical mechanism of these irrigated shallow loess landslides, defining the spatial distributions, 
types and developmental characteristics of loess landslides and surveying and monitoring seasonal agricultural irrigation features and groundwater changes.

Hu et al. [17] explained that the algorithm for calculating the soil erodibility factor (K) in the RUSLE (Revised Universal Soil Loss Equation) is somewhat limited, particularly in the context of China, which features highly diverse soil types. They proposed a modified algorithm addressing the piecewise function of gravel content and relative soil erosion for the first time to modify the soil erodibility factor. They tested the vital key role that gravel content plays in the soil erodibility factor in the Chaohu Lake Basin (CLB) in East China.

Gullies are ones of the most important manifestations of land degradation in a territory. Using Google Earth, Karydas and Panagos [18] carried out a preliminary study on the presence of ephemeral gullies in Greece by sampling representative cultivated fields in 100 sites which were randomly distributed throughout the country for the period 2002-2019. This paper represents the first attempt to use visual interpretation with Google Earth image time-series on a country scale, producing a gully erosion inventory which could be very useful in implementing soil conservation practices such as contour farming and terraces in agricultural areas.

Javidan et al., [19] applied GIS (Geographic Information System) techniques and the MARS (Multivariate Adaptive Regression Splines) algorithm to evaluate gully erosion susceptibility mapping in a specific section of the Gorganroud Watershed in Golestan Province (Northern Iran), covering $2142.64 \mathrm{~km}^{2}$. They also used Google Earth images and field surveys in combination with national reports to generate a map consisting of 307 gully-headcut points. The results showed that the performance of MARS for modelling gully erosion susceptibility can be quite consistent; meanwhile, changes in the testing and validation specimens were investigated. On the other hand, Arabameri et al. [20] successfully tested a new hybrid model combining the index-of-entropy (IoE) model with the weight-of-evidence (WoE) model. They used remote sensing and GIS techniques to map gully-erosion susceptibility in the watershed of the Bastam district of Semnan Province in northern Iran. They considered a total of 303 gullies and eight topographical, hydrological, geological, and environmental conditioning factors. The hybrid model predicted that $38 \%$ of the territory was registered as either highly or very highly susceptible to gullying.

Funding: This research received no external funding.

Acknowledgments: Thanks to all of the contributions to the Special Issue, the time invested by each author, as well as to the anonymous reviewers and editorial managers who have contributed to the development of the articles in this Special Issue. All the guest editors are very happy with the review process and management of the Special Issue and offer their thanks.

Conflicts of Interest: The authors declare no conflict of interest.

\section{References}

1. Panagos, P.; Meusburger, K.; Ballabio, C.; Borrelli, P.; Alewell, C. Soil erodibility in Europe: A high-resolution dataset based on LUCAS. Sci. Total Environ. 2014, 479, 189-200. [CrossRef] [PubMed]

2. García-Ruiz, J.M.; Beguería, S.; Nadal-Romero, E.; González-Hidalgo, J.C.; Lana-Renault, N.; Sanjuán, Y. A meta-analysis of soil erosion rates across the world. Geomorphology 2015, 239, 160-173. [CrossRef]

3. Poesen, J.; Ingelmo-Sanchez, F.; Mucher, H. The hydrological response of soil surfaces to rainfall as affected by cover and position of rock fragments in the top layer. Earth Surf. Process. Landforms 1990, 15, 653-671. [CrossRef]

4. Cerdà, A. Relationships between climate and soil hydrological and erosional characteristics along climatic gradients in Mediterranean limestone areas. Geomorphology 1998, 25, 123-134. [CrossRef]

5. Nadal-Romero, E.; González-Hidalgo, J.C.; Cortesi, N.; Desir, G.; Gómez, J.A.; Lasanta, T.; Lucía, A.; Marín, C.; Martínez-Murillo, J.F.; Pacheco, E.; et al. Relationship of runoff, erosion and sediment yield to weather types in the Iberian Peninsula. Geomorphology 2015, 228, 372-381. [CrossRef]

6. Ruiz-Sinoga, J.D.; Gabarrón Galeote, M.A.; Martinez Murillo, J.F.; Garcia Marín, R. Vegetation strategies for soil water consumption along a pluviometric gradient in southern Spain. Catena 2011, 84, 12-20. [CrossRef] 
7. Rodrigo-Comino, J. Five decades of soil erosion research in "terroir". The State-of-the-Art. Earth-Sci. Rev. 2018, 179, 436-447. [CrossRef]

8. Biratu, A.A.; Asmamaw, D.K. Farmers' perception of soil erosion and participation in soil and water conservation activities in the Gusha Temela watershed, Arsi, Ethiopia. Int. J. River Basin Manag. 2016, 14, 329-336. [CrossRef]

9. García-Ruiz, J.M.; Lana-Renault, N. Hydrological and erosive consequences of farmland abandonment in Europe, with special reference to the Mediterranean region-A review. Agric. Ecosyst. Environ. 2011, 140, 317-338. [CrossRef]

10. Fernández-Raga, M.; Campo, J.; Rodrigo-Comino, J.; Keesstra, S.D. Comparative Analysis of Splash Erosion Devices for Rainfall Simulation Experiments: A Laboratory Study. Water 2019, 11, 1228. [CrossRef]

11. Meshkat, M.; Amanian, N.; Talebi, A.; Kiani-Harchegani, M.; Rodrigo-Comino, J. Effects of Roughness Coefficients and Complex Hillslope Morphology on Runoff Variables under Laboratory Conditions. Water 2019, 11, 2550. [CrossRef]

12. Ferreira, C.S.S.; Walsh, R.P.D.; Kalantari, Z.; Ferreira, A.J.D. Impact of Land-Use Changes on Spatiotemporal Suspended Sediment Dynamics within a Peri-Urban Catchment. Water 2020, 12, 665. [CrossRef]

13. Capello, G.; Biddoccu, M.; Ferraris, S.; Cavallo, E. Effects of Tractor Passes on Hydrological and Soil Erosion Processes in Tilled and Grassed Vineyards. Water 2019, 11, 2118. [CrossRef]

14. Mhiret, D.A.; Dagnew, D.C.; Alemie, T.C.; Guzman, C.D.; Tilahun, S.A.; Zaitchik, B.F.; Steenhuis, T.S. Impact of Soil Conservation and Eucalyptus on Hydrology and Soil Loss in the Ethiopian Highlands. Water 2019, 11, 2299. [CrossRef]

15. Kirchhoff, M.; Engelmann, L.; Zimmermann, L.L.; Seeger, M.; Marzolff, I.; Aït Hssaine, A.; Ries, J.B. Geomorphodynamics in Argan Woodlands, South Morocco. Water 2019, 11, 2193. [CrossRef]

16. Yan, R.-X.; Peng, J.-B.; Huang, Q.-B.; Chen, L.-J.; Kang, C.-Y.; Shen, Y.-J. Triggering Influence of Seasonal Agricultural Irrigation on Shallow Loess Landslides on the South Jingyang Plateau, China. Water 2019, 11, 1474. [CrossRef]

17. Hu, S.; Li, L.; Chen, L.; Cheng, L.; Yuan, L.; Huang, X.; Zhang, T. Estimation of Soil Erosion in the Chaohu Lake Basin through Modified Soil Erodibility Combined with Gravel Content in the RUSLE Model. Water 2019, 11, 1806. [CrossRef]

18. Karydas, C.; Panagos, P. Towards an Assessment of the Ephemeral Gully Erosion Potential in Greece Using Google Earth. Water 2020, 12, 603. [CrossRef]

19. Javidan, N.; Kavian, A.; Pourghasemi, H.R.; Conoscenti, C.; Jafarian, Z. Gully Erosion Susceptibility Mapping Using Multivariate Adaptive Regression Splines-Replications and Sample Size Scenarios. Water 2019, 11, 2319. [CrossRef]

20. Arabameri, A.; Cerda, A.; Tiefenbacher, J.P. Spatial Pattern Analysis and Prediction of Gully Erosion Using Novel Hybrid Model of Entropy-Weight of Evidence. Water 2019, 11, 1129. [CrossRef] 